\title{
PENGARUH KESEHATAN TERHADAP PERCEPATAN PERTUMBUHAN FISIK ANAK USIA 0-2 TAHUN
}

Oleh: Endang Rini Sukamti

Dosen Jurusan Pendidikan Kepelatihan FIK UNY

\begin{abstract}
Abstrak
Pertumbuhan dan perkembangan berlangsung dimulai dari dalam kandungan yaitu semenjak terjadinya pembuahan hingga lahir sampai dewasa. Periode pertumbuhan dan perkembangan fisik maupun mental terjadi tidak hanya sekali tetapi melalui satu tahap ke tahap berikutnya. Ada periode pada saat pertumbuhan dan perkembangan terjadi dengan cepat, melambat, dan stabil.

Anak usia 0-2 tahun merupakan usia yang sangat kritis karena pada usia ini pertumbuhan dan perkembangan fisik maupun mental terjadi dengan cepat dan akan mempengaruhi perkembangan selanjutnya. Banyak faktor yang dapat mempengaruhi cepat atau lambatnya pertumbuhan dan perkembangan antara lain faktor genetik atau keturunan dan lingkungan.

Salah satu faktor lingkungan adalah faktor kesehatan. Seorang ibu yang senantiasa selalu memperhatikan dan menjaga kesehatan anak yang sedang dalam masa pertumbuhan akan berdampak positif terhadap perkembangan fisik maupun mental anak. Adanya perhatian dari orang tua maupun lingkungan sekitar anak akan membawa anak pada tingkat pertumbuhan dan perkembangan yang optimal, sehingga tercipta generasi penerus yang sehat psikis maupun fisik.
\end{abstract}

Kata kunci: kesehatan, pertumbuhan. 
Pada dasarnya setiap manusia mengalami pertumbuhan dan perkembangan semenjak pembuahan sampai menjadi dewasa. Meskipun demikian, terdapat masa-masa tertentu pada saat pertumbuhan dan perkembangan berlangsung cepat yang kemudian relatif lambat, dan stabil. Pada umumnya masa anak-anak khususnya di bawah usia lima tahun, merupakan masa kritis dalam proses pertumbuhan dan perkembangan manusia, karena pada usia ini diletakkan landasan bagi pembentukan jasmani, kepribadian, mental maupun kecerdasan selanjutnya. Pada usia tersebut, khususnya usia 0-2 tahun merupakan masa-masa terjadinya pertumbuhan dan perkembangan baik fisik maupun mental yang sangat pesat akan mempengaruhi pertumbuhan dan perkembangan masa selanjutnya. Pertumbuhan dan perkembangan anak dipengaruhi oleh beberapa faktor, antara lain: faktor keturunan atau genetik, lingkungan dan faktor lainnya. Peranan, pengertian, kesadaran, dan kemampuan orang tua dan anggota keluarga lainnya dalam mengasuh anak pada masa kritis pertumbuhan dan perkembangan anak menjadi faktor yang menentukan dalam proses pembentukan manusia berkualitas yang seutuhnya.

Pertumbuhan dan perkembangan yang dialami anak tidak terjadi secara sembarangan melainkan merupakan suatu rangkaian perubahan yang teratur dari satu tahap ke tahap perkembangan berikutnya. Salah satu kondisi yang dapat mempengaruhi pertumbuhan dan perkembangan adalah faktor kesehatan. Kesehatan seorang bayi sejak dalam kandungan ikut berpengaruh terhadap kelangsungan hidup setelah lahir ke dunia. Oleh karena itu, seorang ibu yang sedang mengandung perlu sekali untuk memperhatikan kesehatan dan makanan bergizi yang dikonsumsinya. Sehat dan tidaknya bayi yang dikandung bergantung pada perawatan seorang ibu.

Berikut ini akan dipaparkan mengenai pengaruh kesehatan terhadap pertumbuhan fisik anak usia 0-2 tahun. Memfokuskan anak usia 0-2 tahun dengan alasan bahwa pada usia tersebut merupakan masa yang penting pada saat pertumbuhan dan perkembangan fisik maupun mental anak terjadi dengan pesat, yang nantinya akan berdampak pada masa selanjutnya.

MEDIKORA Vol. II, No. 2, Oktober 2006: 175 - 190. 


\section{PENGERTIAN PERTUMBUHAN DAN PERKEMBANGAN}

Pertumbuhan dan perkembangan merupakan dua hal yang saling mempengaruhi dan saling berkaitan menjadi satu kesatuan sehingga sulit dipisahkan. Menurut Hurlock (1998) istilah perkembangan dan petumbuhan merupakan dua istilah yang berbeda, walaupun dapat dipisahkan, namun keduanya tidak berdiri sendiri. Pertumbuhan berkaitan dengan perubahan kuantitatif yaitu peningkatan ukuran dan struktur. Anak tidak saja menjadi lebih besar secara fisik, tetapi ukuran dan struktur organ dalam dan otak meningkat. Akibat adanya pertumbuhan otak, anak mempunyai kemampuan yang lebih besar untuk belajar, mengingat, dan berpikir. Anak tumbuh baik secara mental dan fisik. Sebaliknya, perkembangan berkaitan dengan perubahan kualitatif, kuantitatif, atau kedua-duanya secara serempak. Perkembangan adalah bertambahnya kemampuan dalam struktur dan fungsi tubuh yang lebih kompleks dalam pola yang teratur dan dapat diramalkan, sebagai hasil dari proses pematangan. Dengan kata lain menyangkut adanya proses diferensiasi dari selsel tubuh, organ-organ dan sistem organ yang berkembang sedemikian rupa sehingga masing-masing dapat memenuhi fungsinya. Perubahan kuantitatif yaitu perubahan yang bisa diukur atau dihitung, misalnya bertambahnya berat badan, tinggi badan, lebar bahu dan sebagainya, sedangkan perubahan kualitatif adalah perubahan dalam bentuk makin baik, makin lancar, makin teratur, dan sebagainya yang pada dasarnya merupakan perubahan yang tidak bisa atau sukar diukur (Sugiyanto dan Sudjarwo, 1992).

Dalam kaitannya dengan studi perkembangan gerak, pengertian pertumbuhan dan perkembangan menurut Sugiyanto dan Sudjarwo (1992) adalah proses peningkatan yang ada pada diri seseorang yang bersifat kuantitatif atau peningkatan dalam hal ukuran. Misalnya, pertumbuhan fisik terdapat peningkatan ukuran tinggi atau berat badan. Peningkatan tinggi dan berat badan dihasilkan dari terbentuknya bagian baru dari anggota-anggota badan atau unit-unit biologis, misalnya kaki, leher, dan kepala. Contoh pertumbuhan adalah bertambahnya tinggi badan, lebar bahu, dan lebar pinggul. Perkembangan adalah proses perubahan kapasitas fungsional atau kemampuan kerja organ-organ tubuh ke arah keadaan yang makin terorganisasi dan terspesialisasi. Makin terorganisasi 
artinya adalah bahwa organ-organ tubuh makin bisa berfungsi sesuai dengan fungsinya masing-masing. Perkembangan bisa terjadi dalam bentuk perubahan kuantitatif, perubahan kualitatif atau kedua-duanya secara serempak. Perubahan kuantitatif adalah perubahan yang bisa dihitung atau diukur, sedangkan perubahan kualitatif adalah perubahan dalam bentuk makin baik, makin teratur, makin lancer, dan sebagainya yang pada dasarnya merupakan perubahan yang tidak bisa atau sukar diukur.

Pertumbuhan (growth) adalah perubahan dalam besar, jumlah, ukuran atau dimensi tingkat sel, organ maupun individu, yang bisa diukur dengan ukuran berat (gram, pound, kilogram), ukuran panjang ( $\mathrm{cm}$, meter), umur tulang dan keseimbangan metabolik. Perkembangan (development) adalah bertambahnya kemampuan (skill) dalam struktur dan fungsi tubuh yang lebih kompleks dalam pola yang teratur dan dapat diramalkan, sebagai hasil dari proses pematangan. Di sini menyangkut diferensiasi dari sel-sel tubuh, jaringan tubuh, organ-organ dan sistem organ yang berkembang sedemikian rupa sehingga masing-masing dapat memenuhi fungsinya. Termasuk di dalamnya perkembangan emosi, intelektual dan tingkah laku sebagai hasil interaksi dengan lingkungannya (Moersintowarti, 1985; Soetjiningsih, 1995; Markum, 1991 dalam Djauhar Ismail, 1966).

Pertumbuhan fisik mengikuti hukum sefalokaudal dan hukum proksimodistal. Pola sefalokaudal (cephalocaudal pattern) adalah urutan pertumbuhan dengan pertumbuhan terbesar selalu dimulai dari atas-kepaladilanjutkan dengan pertumbuhan fisik mencakup yang besar, berat, serta perkembangan organ tubuh lainnya secara berangsur-angsur dari atas ke bawah (ke leher, bahu, batang tubuh tengah, dan lain-lain). Pola yang sama terjadi pula di wilayah kepala; bagian atas kepala-mata dan otak-bertumbuh lebih pesat dibandingkan dengan bagian bawah, seperti rahang. Suatu proporsi tubuh total yang luar biasa ditempati oleh kepala selama perkembangan prakelahiran dan masa awal bayi (Santrock, 2002)

Santrock (2002) mengatakan bahwa pola proksimodistal (proximodistal pattern) ialah urutan pertumbuhan dengan pertumbuhan dimulai pada bagian tengah tubuh lalu bergerak menuju kaki dan tangan. Contohnya ialah kematangan awal kendali otot batang tubuh dan lengan dibandingkan dengan tangan dan jari.

MEDIKORA Vol. II, No. 2, Oktober 2006: 175 - 190. 


\section{PERIODE PERTUMBUHAN DAN PERKEMBANGAN FISIK}

Pada kenyataannya anak mengalami pertumbuhan dan perkembangan fisik dan mental secara bersama-sama maupun bergantian dan berkesinambungan. Ketika anak bertambah tinggi dan besar, sejalan dengan bertambahnya usia, kemampuan lainnya juga meningkat. Dengan kata lain pertumbuhan dan perkembangan baik fisik maupun mental berjalan seiring.

\section{Perkembangan Prakelahiran}

Perkembangan prakelahiran umumnya dibagi ke dalam tiga periode utama: germinal, embryosis, dan fetal (Santrock, 2002). Periode awal atau germinal (germinal period) ialah periode perkembangan prakelahiran yang berlangsung pada 2 minggu pertama setelah pembuahan. Ini meliputi penciptaan zigot, dilanjutkan dengan pemecahan sel, dan melekatnya zigot ke dinding kandungan. Periode embrionis (embryonic period) ialah periode perkembangan prakelahiran yang terjadi dari 2 hingga 8 minggu setelah pembuahan. Selama periode ini angka pemisahan sel meningkat, sistem dukungan bagi sel tumbuh dan organ-organ mulai tumbuh. Periode fetal (fetal period) ialah periode perkembangan prakelahiran yang mulai 2 bulan setelah pembuahan dan pada umumnya berlangsung selama tujuh bulan. Santrock (2002) mneyebutkan bahwa perkembangan prakelahiran dibagi dalam tiga trisemester sebagai berikut.

\section{Trisemester Pertama}

Pembuahan hingga empat minggu: panjangnya kurang dari 1/10 inci, awal perkembangan susunan tulang belakang, sistem saraf, sistem usus, jantung dan paru-paru. Kantung amniotis membungkus lapisan dasar seluruh tubuh dan disebut ovum.

Pembuahan hingga delapan minggu: panjangnya kurang dari 1inci, wajah sudah berbentuk dengan mata, telinga, mulut dan pucuk gigi yang belum sempurna. Lengan dan kaki bergerak dan otak mulai membentuk. Denyut jantung janin dapat dideteksi dengan ultrasound. Masa ini disebut embrio.

Pembuahan hingga dua belas minggu: panjangnya sekitar 3 inci dan beratnya sekitar 1 ons. Dapat menggerakkan lengan, kaki, jari tangan dan jari kaki. Sidik jari muncul, dapat tersenyum, memberengut, mengisap dan menelan. Jenis kelamin dapat dibedakan, dapat kencing. Usia ini disebut janin. 


\section{Trisemester Kedua}

Pembuahan hingga enam belas minggu: panjangnya sekitar 5,5 inci dan beratnya 4 ons. Denyut jantung kuat, kulit tipis, dan tembus pandang. Rambut halus menutup tubuh, kuku jari tangan dan jari kaki sudah terbentuk. Gerakangerakan terkoordinasi, dapat berguling didalam cairan amniotis.

Pembuahan hingga dua puluh minggu: panjangnya 10 hingga 12 inci dan beratnya $1 / 2$ hingga 1 pon. Denyut jantung bisa didengar dengan steteskop biasa. Menghisap ibu jari. Rambut, bulu mata, alis mata muncul.

Pembuahan hingga 24 minggu: panjangnya 11 hingga 14 inci dan beratnya 1 hingga $1 \frac{1}{2}$ pon. Kulit mengkerut dan tertutup dengan lapisan terlindung (vernix caseosa). Mata sudah terbuka. Meconiom berkumpul di dalam usus besar. Mampu memegang dengan kuat.

\section{Trisemester Ketiga (Tiga Setengah Bulan Terakhir)}

Pembuahan hingga 28 minggu: panjangnya 14 hingga 17 inci dan beratnya $2 \frac{1}{2}$ hingga 3 pon. Bertambah lemak tubuh. Sangat aktif. Gerakan pernafasan yang belum sempurna muncul.

Pembuahan hingga 32 minggu: panjangnya 16 1/2 hingga 18 inci dan beratnya 4 hingga 5 pon. Memiliki periode tidur dan bangun. Berada dalam posisi lahir. Tulang kepala lembut dan lentur. Zat besi disimpan di dalam hati.

Pembuahan dari 36 hingga 38 minggu: panjangnya 19 inci dan beratnya 6 pon. Kulit kurang mengkerut. Vernix caseosa tipis. Lanugo umumnya hilang. Kurang aktif. Memperoleh kekebalan dari ibu.

\section{Periode Pascakelahiran}

Pertumbuhan dan perkembangan pada periode pascakelahiran merupakan lanjutan dari pertumbuhan dan perkembangan pada saat berada dalam kandungan. Hurlock (1998) berpendapat bahwa perkembangan fisik dipandang penting untuk dipelajari, karena baik secara langsung maupun tidak langsung akan mempengaruhi perilaku anak sehari-hari. Secara langsung, perkembangan fisik seorang anak akan menentukan keterampilan anak dalam bergerak. Seorang anak usia 6 tahun yang bangun tubuhnya sesuai untuk usia tersebut, akan dapat melakukan hal-hal yang lazim dilakukan oleh anak berusia 6 tahun. Apabila ia mengalami hambatan atau cacat tertentu, sehingga bangun 
tubuhnya tidak berkembang sempurna, ia jelas tidak mungkin melakukan permainan yang dilakukan teman sebayanya.

Secara tidak langsung, pertumbuhan dan perkembangan fisik akan mempengaruhi bagaimana anak itu memandang dirinya sendiri dan bagaimana ia memandang orang lain. Semua ini akan tercermin dari pola penyesuaian diri anak secara umum. Perkembangan fisik dan perkembangan gerak merupakan dua aspek yang hanya bisa dibedakan tetapi tidak bisa dipisahkan. Perkembangan dan pertumbuhan fisik sangat menentukan terhadap kemampuan fisik untuk melakukan gerakan-gerakan. Makin baik kualitas fisiknya, makin baik pula perkembangan untuk menguasai berbagai macam gerakan.

Perkembangan fisik dan gerak bayi merupakan kelanjutan dari perkembangan yang telah terjadi pada waktu masih janin yang berada dalam kandungan ibunya. Pertumbuhan fisik sejak lahir sampai dewasa dipengaruhi oleh berbagai faktor. Menurut Tanner (1978) seperti yang dikutip oleh Sugiyanto dan Sudjarwo (1992) telah mengidentifikasikan dan mengkategorikan faktorfaktor yang berpengaruh menjadi sembilan macam, yaitu: keturunan, pengaruh gizi, pengaruh perbedaan suku, pengaruh musim dan iklim, pengaruh penyakit, pengaruh himpitan psikososial, pengaruh urbanisasi, pengaruh jumlah keluarga dan status sosial ekonomi, dan kecenderungan sekular. Faktor genetik atau keturunan merupakan sifat bawaan sejak lahir yang diperoleh dari orang tuanya. Ukuran dan bangun tubuh yang diwariskan secara genetik mempengaruhi laju pertumbuhan. Anak-anak yang mempunyai bangun tubuh kekar biasanya akan tumbuh dengan cepat dibandingkan dengan anak-anak yang bangun tubuhnya kecil atau sedang. Faktor pengaruh suku bangsa mengakibatkan terjadinya perbedaan ukuran tubuh rata-rata orang dewasa, kecepatan pertumbuhan, dan bentuk tubuh antarsuku bangsa yang berbeda. Musim dan iklim merupakan faktor lingkungan yang berpengaruh dalam jangka panjang. Pengaruh musim dan iklim cukup besar pada masa adolesensi yang merupakan masa pertumbuhan pesat. Penyakit yang diderita pada masa pertumbuhan berpengaruh terhadap percepatan pertumbuhan. Pengaruh yang diberikan bergantung pada berat ringannya penyakit yang diderita. Faktor lain yang berpengaruh terhadap pertumbuhan, yaitu himpitan psikososial. Hal ini ada kaitannya dengan fungsi hormon pertumbuhan yang menjadi tidak normal. Ketidaknormalan terjadi karena stress yang berlebihan, namun akan menjadi normal kembali apabila 
himpitan psikososial hilang. Pengaruh urbanisasi, jumlah keluarga, dan status sosioekonomik terhadap pertumbuhan fisik merupakan pengaruh tidak langsung. Hal ini berhubungan dengan faktor pemenuhan kebutuhan gizi.

Faktor lain yang berpengaruh, yaitu gizi. Menurut Bogert dalam Panggung (2006) kebutuhan badan untuk pertumbuhan, pemeliharaan, dan reparasi sel-sel yang aus dicukupi dengan makanan, oleh karena itu dalam bahan makanan tersedia bahan-bahan mentah yang sangat dibutuhkan oleh tubuh. Menurut Mc Carrison seperti yang dikutip oleh Panggung (2006) dalam kaitannya pada berbagai suku di India, khususnya di India bagian selatan ditemukan bahwa menu makanannya terdiri atas beras giling, buah-buahan dan susu serta sedikit daging dan sayuran. Penduduk ini berperawakan kecil, tenaga kurang, dan umurnya pendek, sedangkan suku-suku bagian utara dengan susunan menu makanan terdiri dari gandum, cantel, susu, daging, dan mentega mempunyai keadaan fisik yang lebih bagus dan umur yang lebih panjang. Demikian pula dengan hasil penelitian Orr dan Gilks (1931) dalam Panggung (2006) dikatakan, bahwa di Afrika ada dua suku yang bertempat tinggal tidak jauh antara suku dengan yang lainnya, di antara dua suku tersebut adalah suku Masai yang hidupnya beternak, sehingga daging dan susu merupakan makanan hariannya, sedangkan suku Akikuju keadaan makannya kurang baik, terdiri atas jagung dan ketela rambat serta sayuran, sehingga keadaan pertumbuhannya jauh lebih cepat untuk suku Masai. Morison Nestle (1985) seperti yang dikutip Panggung (2006) berpendapat bahwa proses pertumbuhan manusia bergantung pada penyediaan secara terus menerus zat-zat eksogen dan unsur-unsur anorganik lainnya. Kebutuhan gizi-gizi tersebut akan meningkat secara berangsur-angsur dari bayi ke dewasa. Menurut Committee on Dictionary Allowances 1980 kebutuhan makanan untuk orang sehat yang dianjurkan bergantung pada usia, jenis kelamin, tingkat aktivitas, dan iklim, walaupun demikian dalam pemilihan komposisi makanan bergantung pada tingkat sosial budaya dan ekonomi.

Hormon pertumbuhan mempunyai pengaruh terhadap penambahan protein tubuh, menghambat karbohidrat dan menggunakan cadangan lemak sebagai sumber energi. Hormon ini sering disebut somatotropis, merupakan molekul protein kecil yang mengandung 1.988 asam amino. Semua sel tubuh dipengaruhi oleh hormon pertumbuhan. Guyton (1976) berpendapat hormon pertumbuhan mempunyai efek dasar pada proses-proses metabolisme dalam

MEDIKORA Vol. II, No. 2, Oktober 2006: 175 - 190. 
tubuh, yaitu: meningkatkan kecepatan sintetis protein semua sel tubuh, menurunkan kecepatan penggunaan karbohidrat di seluruh tubuh dan meningkatkan mobilisasi lemak dan penggunaan lemak untuk energi. Hormon pertumbuhan menyebabkan terbentuknya suatu zat somatomedin pada hati dan ginjal, kedua zat ini secara langsung berpengaruh dalam meningkatkan pertumbuhan pada tulang. Somatomedin sangat dibutuhkan untuk pengendapan kondritotin sulfat dan kolagen, kedua zat inilah yang memegang peran dalam proses pertumbuhan tulang.

Selain faktor genetik pertumbuhan fisik juga dipengaruhi oleh faktor lingkungan baik lingkungan pralahir anak maupun lingkungan pascalahirnya. Faktor lingkungan pralahir misalnya kekurangan gizi, merokok, dan tekanan batin yang dialami ibu yang sedang mengandung, dapat mempengaruhi besar kecilnya ukuran bayi ketika dilahirkan dan pengaruh ini akan berlangsung terus sampai si anak mencapai ukuran akhirnya.

Perkembangan Tulang

Seiring dengan bertambahnya usia anak pertumbuhan dan perkembangan fisik juga bertambah. Otot, tulang, dan sendi, serta saraf tumbuh dan berkembang. Perkembangan tulang yang terjadi pada setiap manusia biasanya mencakup pertumbuhan tulang (ukurannya berubah), perubahan jumlah tulang dan perubahan komposisi tulang. Perkembangan tulang sejalan dengan kecenderungan pertumbuhan umumnya, yaitu pada tahun pertama pertumbuhan cepat sekali, kemudian lambat, dan pada saat remaja menjadi cepat sekali.

Pertumbuhan tulang terjadi karena memang ada pemanjangan pada ujung tulang. Pengerasan tulang terjadi setelah seseorang dilahirkan dan akan berlangsung terus sampai masa remaja dan pada akhir masa remaja pengerasan tulang telah dapat dikatakan sempurna. Proses pengerasan tulang dimulai dari pusat pengerasan di dalam tulang rawan yang menyebar ke seluruh tulang. Setelah pengerasan terjadi dengan sempurna, setiap tulang akan memperlihatkan ciri tersendiri dengan bentuknya masing-masing. Proses pengerasan tulang tidak seragam untuk semua tulang, dengan kata lain setiap bagian tulang tertentu mempunyai tempo pengerasan masing-masing. Pengerasan dapat terjadi bergantung pada hormon yang dikeluarkan oleh kelenjar tiroid. Apabila terjadi kekurangan produksi hormon ini, pengerasan tulang akan tertunda. Juga ada hubungan yang erat antara pengerasan tulang dan makanan yang bergizi. Apabila 
anak-anak kurang mendapat perhatian dalam hal pemberian makanan yang bergizi, zat mineral yang diperlukan tulang berkurang dan proses pengerasan tulang juga terhambat (Hurlock, 1998).

\section{Perkembangan Otot}

Di samping berat tulang, berat tubuh seseorang juga ditentukan oleh otot dan adipose atau lapisan lemak. Pada tahun-tahun pertama kehidupannya adipose akan berkembang lebih cepat daripada otot. Pada saat seseorang dilahirkan, dia sudah mempunyai serabut otot, tetapi masih belum berkembang. Setelah kelahirannya, serabut ini akan berubah ukuran, bentuk, dan komposisi. Panjang, lebar, dan ketebalan otot ini akan mengalami proses pertumbuhan. Memasuki usia dewasa, otot ini telah berkembang sebanyak lima kali dari saat ia dilahirkan. Anak-anak yang perkembangan ototnya penuh biasanya mempunyai kekuatan yang lebih besar dibandingkan dengan mereka yang ototnya ramping, yang biasanya lebih gesit dan koordinasi otot dalam bergerak lebih baik daripada yang berotot banyak. Ada beberapa anak yang ototnya mudah lelah dan ada juga anak yang ototnya mempunyai daya tahan yang luar biasa.

Jumlah lapisan adipose yang dimiliki seseorang tidak hanya bergantung pada faktor keturunan tetapi juga pada kecenderungan bentuk tubuhnya di kemudian hari, kebiasaan makan, dan juga karena faktor usia. Dalam perkembangan pembentukan sel lemak, terdapat tiga periode kritis yaitu: periode pertama selama 3 bulan terakhir kehidupan pralahir, periode kedua selama 2 sampai 3 tahun kehidupan pascalahir, dan periode ketiga antara usia 11-13 tahun, yaitu memasuki usia remaja (Hurlock, 1998).

\section{Perkembangan Susunan Saraf}

Pertumbuhan susunan saraf dapat dikatakan berlangsung dengan cepat sekali selama dalam kandungan dan 3 sampai 4 tahun pertama setelah dilahirkan. Selama dalam kandungan susunan saraf yang terutama tumbuh cepat adalah jumlah dan ukuran sel saraf. Dalam perkembangan setelah dilahirkan, pertumbuhan susunan saraf lebih terarah pada pengembangan sel saraf yang masih belum berkembang. Setelah anak berusia lebih dari 4 tahun, pertumbuhan susunan saraf berlangsung sedikit lebih lambat.

MEDIKORA Vol. II, No. 2, Oktober 2006: 175 - 190. 
Ketika dilahirkan otak bayi beratnya satu perdelapan dari berat tubuh seluruhnya, pada usia 10 tahun berat otak akan satu perdelapan belas berat tubuh dan pada usia 15 tahun berat otak akan satu pertiga puluh berat tubuh dan pada usia dewasa akan mencapai berat satu perempat puluh berat tubuh seluruhnya. Pertumbuhan dan perkembangan otak serta seluruh susunan saraf, mempengaruhi seluruh aspek perkembangan anak.

Klasifikasi perkembangan usia menurut Mak'mun (2000) ada tujuh, yaitu prenatal (prakelahiran), bayi (lahir hingga usia 24 bulan), kanak-kanak ( 2 tahun sampai 10 tahun), remaja (10 sampai 20 tahun), dewasa awal (20 sampai 40 tahun), dewasa pertengahan (40 sampai 60 tahun) dan lanjut usia (60 tahun ke atas). Masa bayi diklasifikasikan lagi, yaitu: neonatal (lahir- usia 1 bulan), bayi awal (usia 1 bulan-12 bulan), dan bayi akhir (usia 12 bulan-24 bulan). Pada pembahasan ini dikhususkan pada pertumbuhan dan perkembangan bayi yang diklasifikasikan dalam tiga tahap, yaitu: neonatal, bayi awal, dan bayi akhir.

\section{PERKEMBANGAN GERAK ANAK USIA 0-2 TAHUN}

\section{Neonatal (Lahir-Satu Bulan)}

Pada usia ini bayi harus melakukan penyesuaian kehidupan pascalahir. Periode kelahiran ini merupakan periode penyesuaian fungsi-fungsi fisiologis dan sensori. Menurut Hurlock (1998) terdapat empat penyesuaian utama yang harus dilakukan setiap bayi yaitu penyesuaian terhadap perubahan temperatur, penyesuaian terhadap pernapasan, penyesuaian terhadap makanan, dan penyesuaian terhadap pembuangan.

Gerakan-gerakan bayi yang baru lahir merupakan gerakan refleks. Sifat refleks ini adalah otomatis dan berada di luar kendali bayi yang baru lahir tersebut. Santrock (2002) berpendapat bahwa sifat ini merupakan inheren (built in) terhadap rangsang tertentu dan memberi bayi-bayi kecil respons penyesuaian diri terhadap lingkungan sebelum mereka memiliki kesempatan untuk belajar banyak. Refleks itu misalnya mengisap dan mencari, refleks ini akan hilang seiring dengan bertambahnya usia bayi. Berbatuk, mengejapkan mata, dan menguap merupakan refleks yang muncul pada saat bayi lahir dan akan tetap ada sepanjang hidupnya.

Pertumbuhan fisik bayi, baik sebelum dilahirkan dan selanjutnya sesudah dilahirkan akan mengalami perubahan terus-menerus dalam bentuk dan proporsi 
ukuran bagian-bagian tubuhnya sejalan dengan pertambahan ukuran yang menjadi makin besar dan makin panjang atau tinggi. Tinggi dan berat badan bayi pada beberapa hari awal kelahiran biasanya mengalami penurunan sebelum mereka belajar menyesuaikan diri dengan kegiatan makan yang terjadi setelah kelahiran. Setelah bayi menyesuaikan diri dengan cara mengisap, menelan, dan mencerna, mereka akan tumbuh dengan cepat. Dari lahir hingga usia setahun, bayi manusia bertambah tiga kali lipat beratnya dan bertambah panjangnya 50 persen (Santrock, 2002). Berikut ini gambar perbandingan postur antara bayi, anak, remaja, dan dewasa.

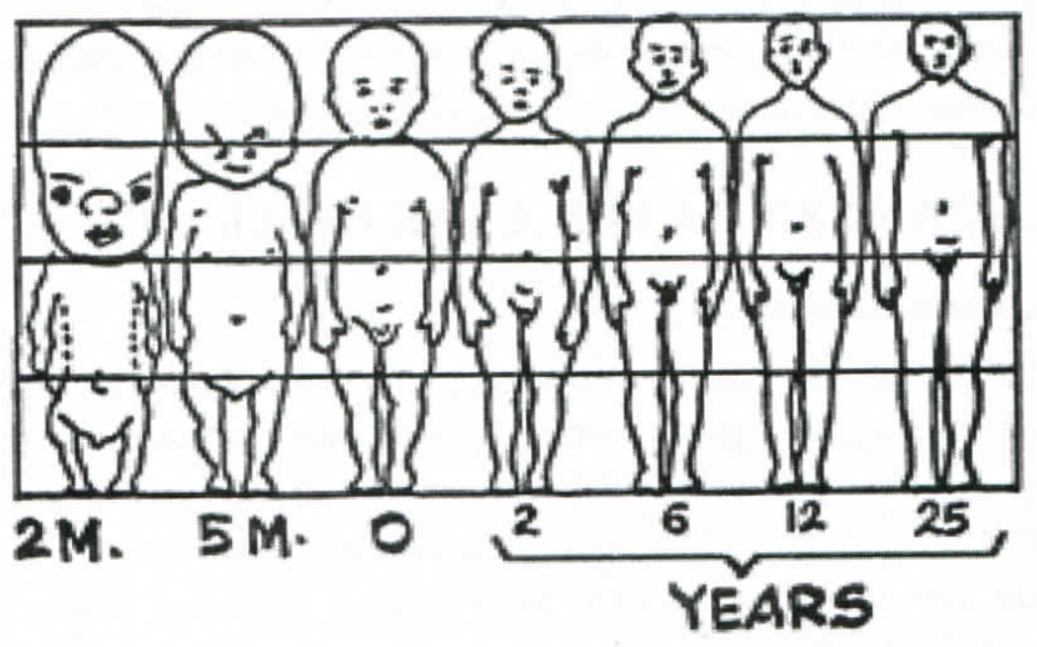

Gambar 1. Perbandingan Postur antara Bayi, Anak, Remaja, dan Dewasa (Brooks, G.A \& Fahley, T.D., 1984: 665)

\section{Keterangan:}

Bayi 2 bulan dalam kandungan: kepala 1/4 bagian dari tubuh

Bayi 6 bulan dalam kandungan: pertumbuhan kepala menjadi perubahan tungkai bawah, anak umur dua tahun: togok (trunk) dan tungkai bawah panjangnya sama. Anak umur 2 tahun: kaki tetap bertambah dengan cepat dibanding dengan togok. Dewasa: tungkai bawah lebih panjang dibanding dengan togok.

MEDIKORA Vol. II, No. 2, Oktober 2006: 175 - 190. 
Menurut Sugiyanto dan Sudjarwo (1992) adaptasi fisiologis merupakan faktor utama di dalam masa peralihan. Masa peralihan di sini yaitu peralihan dari kehidupan dalam kandungan dengan lingkungan barunya setelah ia lahir ke dunia. Dengan terlewatinya masa peralihan, bayi akan mengalami masa pertumbuhan dan perkembangan. Proses pematangan fungsi organ-organ tubuh akan terjadi. Pertumbuhan adalah perubahan fisik dan biologis yang dapat diukur. Kematangan adalah rangkaian mekanisme intrinsik yang memelihara keseimbangan dan arah pola pertumbuhan secara keseluruhan. Pertumbuhan dan kematangan akan mewarnai perkembangan perilaku bayi. Perkembangan perilaku tersebut bisa disempurnakan melalui proses belajar dalam bentuk aktivitas berulang-ulang.

Pada saat lahir, bayi tidak memiliki koordinasi dada atau lengan yang baik, tetapi pada bulan kedua bayi dapat menegakkan kepalanya dalam posisi tengkurap. Keterampilan tangan yang dimiliki bayi pada usia ini, yaitu mengisap jempol.

\section{Usia 1 Bulan - 12 Bulan}

Pada usia 3 bulan bayi dapat menyangga dadanya dengan menggunakan lengannya untuk menopang pada saat ia tengkurap. Pada usia 3-4 bulan bayi dapat berguling, dan pada usia 4-5 bulan bayi dapat menopang sebagian berat badannya dengan kaki mereka. Pada usia kira-kira 6 bulan bayi dapat duduk tanpa dukungan, dan pada usia 7 bulan mereka dapat merangkak dan berdiri dengan dukungan. Pada usia kira-kira 8 bulan, bayi dapat menyangga tubuh mereka hingga ke posisi berdiri, pada usia kira-kira 10-11 bulan mereka dapat berjalan menggunakan kursi atau meja sebagai alat bantu, dan pada usia 12-13 bulan bayi pada umumnya dapat berjalan tanpa bantuan (Santrock, 2002).

\section{Usia 12 Bulan - 24 Bulan}

Pada usia 13-18 bulan anak-anak yang baru belajar berjalan dapat menarik suatu mainan yang diikat dengan tali atau benang, menggunakan kedua tangan atau kaki untuk memanjat sejumlah anak tangga, dan mengendarai mainan roda empat (White dalam Santrock, 2002). Pada usia 18-24 bulan, anak-anak yang baru belajar berjalan dapat berjalan cepat atau berlari dengan susah payah untuk suatu jarak yang pendek, menyeimbangkan kaki mereka dalam posisi berjongkok 
sambil bermain dengan benda-benda di atas lantai, berjalan mundur tanpa kehilangan keseimbangan, berdiri dan menendang bola tanpa terjatuh, berdiri dan melemparkan bola, dan melompat di tempat (Schirmer dalam Santrock, 2002).

\section{PENGARUH KESEHATAN TERHADAP PERTUM- BUHAN FISIK}

Di atas telah disebutkan bahwa salah satu faktor yang dapat mempengaruhi pertumbuhan dan perkembangan fisik anak adalah kesehatan. Seorang ibu yang sedang mengandung harus senantiasa menjaga kesehatan baik dirinya maupun calon bayi yang sedang dikandungnya. Hurlock (1998) menyebutkan bahwa selama periode pralahir, terdapat banyak bahaya, seringkali lebih serius dan mempunyai pengaruh yang lebih jauh daripada yang dibayangkan orang. Bahaya ini bersifat fisik dan psikologis. Kemungkinan bahaya fisik yang paling umum dan merusak selama periode pralahir adalah ketidakteraturan perkembangan, keguguran, dan kelahiran kembar. Bahaya psikologis yang paling umum dan berbahaya selama periode pralahir ialah keyakinan tradisional mengenai pengaruh pralahir, stress yang dialami calon ibu, dan sikap yang tidak menguntungkan dari orang yang berarti terhadap anak yang akan lahir.

Menurut Olson (1959) dengan adanya gangguan kesehatan pada anak dapat menyebabkan berkurangnya nafsu makan, sehingga pertumbuhan fisik dapat terganggu. Demikian pula hasil penelitian Martin dkk (1985) mengatakan anak yang menderita sakit berat dan dengan nutrisi ketat dalam waktu yang lama dapat mengganggu proses pertumbuhan fisik. Hal ini disebabkan oleh salah satu fungsi makan adalah menyediakan bahan-bahan bagi pembangunan tubuh (pertumbuhan) dan pemeliharaan sel-sel tubuh.

Kesehatan dan pemberian makanan bergizi terutama pada tahun pertama kehidupan seseorang juga menentukan kecepatan atau kelambatan pertumbuhan (Hurlock, 1998). Seorang anak yang memperoleh perawatan memadai, biasanya akan tumbuh dengan cepat dan anak yang kurang memperoleh perawatan kesehatan dan gizi yang memadai, akan mengalami kelambatan dalam pertumbuhannya. Anak-anak yang memperoleh imunisasi teratur untuk mencegahnya dari berbagai macam serangan penyakit, juga merupakan faktor penting. Anak-anak ini akan tumbuh lebih cepat karena jarang sakit dan lebih

MEDIKORA Vol. II, No. 2, Oktober 2006: 175 - 190. 
sehat dibandingkan dengan anak yang sering sakit karena kurang teraturnya imunisasi.

Pengaruh gizi terhadap pertumbuhan fisik sesudah bayi lahir menurut Tanner (1978) dalam Sugiyanto dan Sudjarwo (1992) dibedakan dalam empat macam pengaruh, yaitu: pengaruh kecepatan pertumbuhan, ukuran tubuh setelah dewasa, bentuk tubuh, dan komposisi jaringan tubuh. Pada anak-anak yang mengalami kekurangan gizi dalam peiode waktu tertentu yang agak lama akan mengalami kelambatan pertumbuhan. Selain itu, penyakit yang diderita pada masa-masa pertumbuhan berpengaruh terhadap kecepatan pertumbuhan. Pengaruh yang diberikan bergantung pada berat-ringannya penyakit yang diderita. Penyakit yang ringan pengaruhnya kecil, namun meskipun penyakitnya ringan tetapi terlalu sering diderita, pengaruhnya menjadi makin nyata. Penyakit yang cukup berat, pengaruhnya cukup besar, yaitu pertumbuhan menjadi lambat.

\section{KESIMPULAN}

Dari uraian-uraian di atas dapat disimpulkan bahwa usia 0-2 tahun merupakan usia penting dalam masa pertumbuhan dan perkembangan, baik fisik maupun mental dan akan berpengaruh pada perkembangan selanjutnya. Seorang ibu yang sedang mengandung harus senantiasa menjaga kesehatan dan makan makanan yang bergizi selama kehamilan, sehingga bayi yang dikandungnya dapat tumbuh dan berkembang dengan baik. Demikian juga orang tua yang memiliki anak dalam masa pertumbuhan harus memperhatikan kesehatan dan memberikan makanan yang bergizi kepada anak-anaknya. Anak yang sehat akan lebih cepat tumbuh dan berkembang dibandingkan anak yang tidak sehat dan sering sakit.

Kesehatan sangat penting artinya bagi anak-anak dalam masa pertumbuhan dan perkembangan baik fisik maupun mental. Kesehatan di sini meliputi kesehatan psikis maupun fisik. Oleh karena itu agar anak tumbuh dan berkembang dengan optimal setiap orang tua harus selalu memperhatikan kesehatan dan kebutuhan gizi anak-anaknya. Kekurangan gizi bisa menyebabkan pertumbuhan lambat dan kelebihan gizi bisa menyebabkan kegemukan (obesitas). 


\section{DAFTAR PUSTAKA}

Amung Ma'mun dan Yudha M. Saputra. (2000). Perkembangan Gerak dan Belajar Gerak. Jakarta: Depdikbud, Dirjen Pendidikan dasar dan Menengah.

Djauhar Ismail. (1996). "Menyiapkan Sumberdaya Manusia/Generasi Penerus yang Tangguh sejak Awal Kehidupan." Seminar Tumbub Kembang Anak. Yogyakarta: Fakultas Kedokteran UGM.

Hurlock, Elizabeth B. (1998). Perkembangan Anak (terjemahan). Jakarta: Penerbit Erlangga. Santrock, John W. (2002). Perkembangan Masa Hidup (terjemahan). Jakarta: Penerbit Erlangga. Pamuji Sukoco. (2004). "Perkembangan Motorik Murid Sekolah Dasar Purwomartani." Laporan Penelitian. Yogyakarta: FIK UNY.

Panggung Sutapa. (2006). “Pengembangan Motorik Anak Prasekolah.” Makalab Seminar. Yogyakarta: Universitas Negeri Yogyakarta.

Sugiyanto dan Sudjarwo. (1992). Perkembangan dan Belajar Gerak. Jakarta: Depdikbud. 